CORRECTION

\title{
Correction: Defending an inclusive right to genital and bodily integrity for children
}

Kate Goldie Townsend (iD

(c) The Author(s) 2022

IJIR: Your Sexual Medicine Journal; https://doi.org/10.1038/s41443-022-00545-9

Correction to: International Journal of Impotence Research https://doi.org/10.1038/s41443-021-00503-x, published online 2 December 2021

For this article parts of the text have been converted to footnotes. They read as follows:

The Brussels Collaboration on Bodily Integrity [10] defines 'medically necessary' in the following way: '(1) the bodily state poses a serious, time-sensitive threat to the person's well-being, typically due to a functional impairment in an associated somatic process, and (2) the intervention, as performed without delay, is the least harmful feasible means of changing the bodily state to one that alleviates the threat'.

By 'our', 'we', and 'us', I mean all embodied people.

\begin{abstract}
(c) Open Access This article is licensed under a Creative Commons Attribution 4.0 International License, which permits use, sharing, adaptation, distribution and reproduction in any medium or format, as long as you give appropriate credit to the original author(s) and the source, provide a link to the Creative Commons license, and indicate if changes were made. The images or other third party material in this article are included in the article's Creative Commons license, unless indicated otherwise in a credit line to the material. If material is not included in the article's Creative Commons license and your intended use is not permitted by statutory regulation or exceeds the permitted use, you will need to obtain permission directly from the copyright holder. To view a copy of this license, visit http://creativecommons. org/licenses/by/4.0/.
\end{abstract}

C The Author(s) 2022 